\title{
An Empirical Research on HR and Organizational Behaviour Intervention to Sustain B2b Business Relationship in Cross
}

\author{
N. Madhumithaa, K.K. Sree Devi
}

\begin{abstract}
From 2011 till now, major challenge that auto component manufacturers are facing is with regard to sharply rising imports of auto component from ASEAN countries such as Thailand, China and Japan. Due to the implementation of Free Trade Agreement between India and ASEAN countries in 2011, this prevails to be worrisome for Indian component makers.

In this competitive global market supplier should maintain good relationship with buyer to be successful. But it becomes difficult when they are trying to operate in international context facing more challenges related to substantial cultural, religious and ethical difference between the firms. This critical to the researcher to analyse and understand about different national and organizational culture and their influence on the way, people do business and view the world.

The purpose of this research is to identify the areas in which Indian Auto-component Manufacturers (IACMs) have brought change to sustain the business relationship with MNC Original Equipment Manufacturers (OEMs) and the role of $H R$ Interventions and organizational behavior in strengthening the business relationship. The target population involves large and medium scale auto component manufactures supplying to MNC OEMS, Exporting or after-market, which are located in Chennai. Questionnaire was administered to all the five functional heads of 56 auto component manufacturers in Chennai.
\end{abstract}

Key words: Cross cultural buyer-supplier relationship, adoption, organizational behavior, organizational structure and HR Interventions.

\section{INTRODUCTION}

Economic reforms 1991, brought liberalization in foreign direct investment and abolition of industrial licensing caused biggest of an ever positive wave in automobile sector where more domestic and foreign automobile manufacturers and auto component market entered into Indian market. A prominent foreign automobile manufactures brought their subsidiaries to supply critical component to them was yet another context.

From 2011 till now, major challenge that auto component manufacturers are facing is with regard to sharply rising imports of auto component from ASEAN countries such as Thailand, China and Japan. Due to the implementation of Free Trade Agreement between India and ASEAN countries in 2011, this prevails to be worrisome for Indian component makers. It indicates that supply chain are becoming global.

In this competitive global market supplier should maintain good relationship with buyer to be successful. But it becomes difficult when they are trying to operate in international context facing more challenges related to substantial cultural, religious and ethical difference between the firms. This critical to the researcher to analyse and understand about different national and organizational culture and their influence on the way, people do business and view the world.

This study identifies the areas in which Indian AutoComponent manufacturers have adopted the various managerial policies according to the MNC Automobile manufacturers to have successful and sustainable relationship.

\section{REVIEW OF LITERATURE}

Adoption is a series of activities or changes, which suppliers adopts or performs to satisfy the customer/buyer to sustain the business relationship. Adoption and shared values are common behavior, goals and policies among partners. Morgan and Hunt (1994)argue that these above mentioned factors influences both commitment and trust in relationship. According to organization behavior theories it is said that more one share's their companies' partner value the more commitment is establishes among their relationship.

Four type of acculturation modes are differentiated by Berry and Sam as stated below:

(i) Adoption of the dominant culture is done through assimilation process.

(ii) Rejecting one's own culture without adopting or refusing the dominate culture is called as Marginalization.

(iii) Retention of one's own culture without adopting the dominant culture is done through process called as separation.

(iv) Finally, maintaining one's own culture and adopt the dominant culture in parallel is practiced through integration.

To follow the above mentioned acculturation modes cross-cultural knowledge is required, which is acquired knowledge through experience in the field.Based on the above fact, this research paper tries to ascertain the areas in which the adoption has been taken place in IACMs firm to sustain the business relationship with their MNC OEM buyers.

Revised Manuscript Received on September 10, 2019.

Dr. N. Madhumithaa, Assistant Professor (S.G), School of Management, Hindustan Institute of Technology and Science, Chennai, Tamilnadu, India.

(email: madhuphd1316@gmail.com)

Dr.K.K. Sree Devi, Assistant Professor (S.G), School of Management, Hindustan Institute of Technology and Science, Chennai, Tamilnadu, India.

(email: sreedevi@hindustanuniv.ac.in). 


\section{METHODOLOGY \& RESULTS}

This study considers the use of descriptive research methodology (Churchill, 1976) and positivist quantitative approach (Easterby-Smith et al., 2008). Descriptive research describes characteristics of population or phenomenon. It seeks to determine answers for questions like who, what, when, where and how. Descriptive research design has been selected because it provides an accurate portrayal or account of characteristics. And positivist quantitative approach is adopted to quantify the observations and to follow deductive method to give explanation for each area of adoption by IACMs. The major areas in which changes have been adopted have been identified using the mean analysis and the results are interpreted.

Table 1: Sectors in which Changes / Adoption are made by India Auto Component MSEMs to meet the need there MNC OEM Customers

\begin{tabular}{|c|c|c|c|c|c|c|c|c|}
\hline \multirow{2}{*}{ Adoption Made in } & \multirow[b]{2}{*}{$\mathrm{N}$} & \multirow[b]{2}{*}{ Mean } & \multirow[b]{2}{*}{$\begin{array}{c}\text { Std. } \\
\text { Deviation }\end{array}$} & \multirow[b]{2}{*}{$\begin{array}{c}\text { Std. } \\
\text { Error }\end{array}$} & \multicolumn{2}{|c|}{\begin{tabular}{|l|}
$95 \%$ Confidence \\
Interval for Mean
\end{tabular}} & \multirow[b]{2}{*}{ Minimum } & \multirow[b]{2}{*}{ Maximum } \\
\hline & & & & & $\begin{array}{l}\text { Lower } \\
\text { Bound }\end{array}$ & $\begin{array}{l}\text { Upper } \\
\text { Bound }\end{array}$ & & \\
\hline Product & 280 & 3.00 & .568 & \begin{tabular}{|l|}
.034 \\
\end{tabular} & 2.93 & 3.07 & 2 & 4 \\
\hline People & 280 & 2.23 & .591 & .035 & 2.16 & 2.30 & 1 & 3 \\
\hline $\begin{array}{l}\text { Inventory \& } \\
\text { Distribution }\end{array}$ & 280 & 3.03 & .663 & .040 & 2.95 & 3.11 & 2 & 4 \\
\hline $\begin{array}{l}\text { Investment in Capital } \\
\text { Equipments\& Tools }\end{array}$ & 280 & 3.40 & .572 & .034 & 3.33 & 3.47 & 2 & 4 \\
\hline $\begin{array}{l}\text { Management } \\
\text { Policies }\end{array}$ & 280 & 3.48 & .574 & .034 & 3.41 & 3.55 & 3 & 5 \\
\hline Total & 1400 & 3.03 & .741 & .020 & 2.99 & 3.07 & 1 & 5 \\
\hline
\end{tabular}

Figure 1: Sectors in which Changes / Adoption are made by Indian Auto Component MSEMs to meet the need there MNC OEM Customers

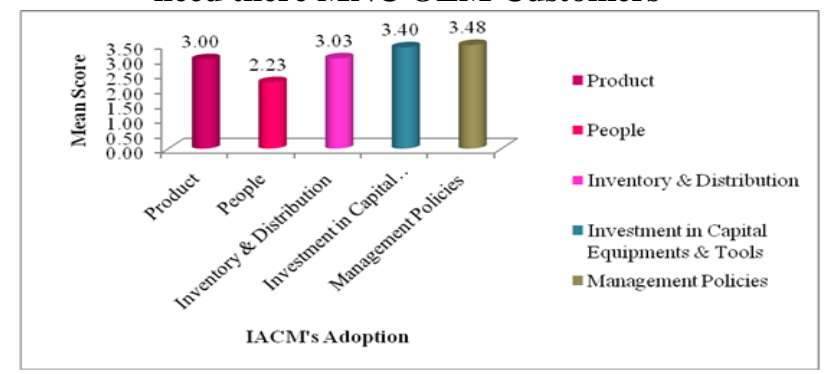

\section{Inference}

Most of the firms have changed their management policy (Mean value 3.48) to suit the requirements of their buyers; next major change was in investment decision (Mean value 3.40) which is done to bring change in technology in-order to enhance quality of the product, it is also demonstrated in this analysis where IACMs have changed their product (Mean value 3.00) and minor changes were noticed in Inventory management (Mean value 3.03), hiring and firing people was very less (Mean value 2.23).

From the above analysis it can be clearly interpreted that adoption characteristics among established IACMs were found to confirm with the oligopolistic reaction theory, which stress that firms become multinational in order to match the actions of other member of oligopoly, which adopt the same cultural background of their buyer.

The concept here is that firms imitate each other's actions to reduce the risk of being different. By imitating competitors, the risks associated with the internationalization process are reduced. Apart from the analysis of adoption technique among IACMs, observation during this study indicates that shifts are not easily visible. But they can lead completely new perspective on operation of markets, which in turn, can cause decisions to be taken that no one could have conceived in advance.

Thus, the strategic consequences of ongoing activities (adoption area) may be as significant as the strategic decision made. This is clearly highlighted in the change management style analysis, how each adoption has played its role to bring in successful transformation process in organization.

Corporate vision benefit in successful transformation process

While analyzing the adoption area in IACM firms, it is important to analyze the major adoption / change area i.e., Management policy (Mean vale - 3.48), with the fact that successful corporate creeds and visions vitalize the corporate culture as an umbrella culture and also bring about an outstanding transformation / organizational performance. So through manual method, conceptual analysis was carried out to examine the vision and creed statements of ten selected well established IACMs through which some success factors for business can be explored. This research identified the content, the expression and formation of successful creeds.

Table 2: Content analysis on vision statement of Five selected IACMs

\begin{tabular}{|l|l|l|}
\hline Company Name & Vision Statements & $\begin{array}{l}\text { Frequen fly used words } \\
\text { and Phrases (Concep tual } \\
\text { Analysis) }\end{array}$ \\
\hline $\begin{array}{l}\text { M.K. Auto } \\
\text { Components }\end{array}$ & $\begin{array}{l}\text { To maintain and improve customer } \\
\text { satisfaction by delivering quality } \\
\text { parts, in time, at minimizad cost }\end{array}$ & $\begin{array}{l}\text { Customer satisfaction, } \\
\text { excellence in quality and } \\
\text { cost }\end{array}$ \\
\hline Devandra Exports & $\begin{array}{l}\text { To deliver Reliable, Cost Effective } \\
\text { and Innovative Quality Products } \\
\text { and Services to the satisfaction of } \\
\text { our customers without } \\
\text { compromising on Trust and } \\
\text { Integrity }\end{array}$ & $\begin{array}{l}\text { Innovative, customer } \\
\text { satisfaction, progressive } \\
\text { growth }\end{array}$ \\
\hline Rane Brake lining & $\begin{array}{l}\text { To establish global presence and } \\
\text { enhance domestic leadership by } \\
\text { providing eco-friendly friction } \\
\text { solutions. }\end{array}$ & $\begin{array}{l}\text { Growth, respect for } \\
\text { customers }\end{array}$ \\
\hline $\begin{array}{l}\text { Taksta joint } \\
\text { venture with Anand }\end{array}$ & $\begin{array}{l}\text { To Create Value Sustainably } \\
\text { Through Pursuit of Excellence and } \\
\text { Good Govemance }\end{array}$ & Pursuit of excellence \\
\hline
\end{tabular}

\section{i) Contents of Successful creeds / vision}

Three factors seem important in the contents of creeds and visions. These three elements promote the interest of stake holders, who are the back bone for the transformation process.

- Customer orientation, or superior customer service

- Progressiveness, innovativeness, or the pursuit of excellence

- $\quad$ Respect for employees and respect for individuals 


\section{ii) The expression of successful creeds / vision}

Through content analysis it was found that, successful corporate creeds use words and phrases which appeal to sentiments, enhancing the emotion of the members.

\section{iii) Formation of creeds / vision}

In this research it was found that, a recent trend in the formulation of a new creed and vision is involving teams of young mangers. Where young managers had long term expectations for the company because they had the possibility to stay longer than the current higher level management. Their longer term future in the company makes them more serious about the future of the company.

Organizational structure and Human Resource Management system required for Sustaining and strengthening business relationship

As indicated by the adoption made among IACM Firms and attitude formation, management policies are an important aspect that needs change for creating vitalized culture in organization which in turn helps in creating trust. In-depth interview was carried on with Human Resource Manager (HRM) and Production Manager (PM) in wellestablished IACM Firm.

Based on the interview it was found that there are three principles used by HRM and PM to invigorate corporate culture that helps in creating trust among employees for bringing about the transformation required by buyers. The three principles are Organizational setting, Organizational structure and, systems and rules.

\section{I) Organizational Setting}

This study is interested in examining IACM member's attitude towards transformation required by MNC OEMs and how organizational settings affect such attitude. Organizational setting can also be called as physical work environment. Through interview the following changes in organizational setting are identified, which helped in trust formation in organization.

1. Automated production facility

2. Large rooms

3. Uniforms

\section{1) Automated production facility:-}

Production manager expressed his experience that, "old equipment, with its associated lower productivity, tends to require simple manual work that falls into the category of work which doesn't attract good employees and does not stimulate fresh ideas. To create more pleasant workplace is a basic sign of respect for those who work within them, so automation process was introduced". It was found that an automated, but flexible, manufacturing system produces a variety of specifications in small lots, in order to realize a market segmentation policy. For this setting more mental activity is required than in long and unchanging production run such automation reduces fatigue, which in turn motivates the employees to enhance their skill.

During the field interview, HR manager quoted that "Job Enlargement and Job Enrichment practices were followed, mostly through methods like job rotation and quality circle formation"; to facilitate implementation of automated production facility.
The most important point with regard to this study is that automation is necessary to improve the quality of products and to reduce cost, which is the most expected outcome by MNC OEM buyers from IACMs. Without modernized equipment, it is much harder for a company to survive competitively where there is a high threat to local players due to Make-in India campaign.

\section{2) Large Rooms:-}

During interview production manager have highlighted that office layout / plant layout influenced communication pattern and idea generation. Their opinion was that, large rooms stimulate communication and brainstorming effects through frequent discussions.

\section{3) Uniforms:-}

Through observation during this research work, it is noted that most of IACM firms - all the cadres, from the director of the plant till the office workers wear the same suit. The purpose of the uniform was to enhance the sense of identification with the organization and the sense of equality, and shortens the social distance between members.

\section{II) Organizational Structure}

Through the interview with production manager and HR manager it was found that, for creating trust among employees the following features of organizational structure was introduced.

1) Strong strategic planning department

2) Centralized strategic decision and decentralized operational decisions

3) Interfacing departments

\section{1) Strong Strategic planning department:-}

The firm selected for conducting in-depth interview had strategic planning department, where this department links planning departments in head office with research laboratories, incubator departments and production teams. These departments plan future innovation.

The reason for creating incubator department was to develop new products as prototypes which normally cannot be taken care in the routine production line. The production line is normally busy producing for regular orders, hence cannot concentrate on innovations. Hence the innovation is fostered through incubator and strategic planning department.

\section{2) Centralized strategic decision and decentralized} operational decisions

The IACMs changed their organizational structure from a functional organizational model to a product division. The reasons being when product divisions were organized by technology, the decisions tended to be technology-oriented, so the firms changed organizational structure towards one that is more customer-oriented. Groups and sections are organized according to the customers. The IACM firms had also reorganized its sales team from product based to customer based teams. 


\section{3) Interfacing between departments}

Some successful IACMs used "DPS" project team which was composed of members from Development (D), Production (P) and Sales department (S). MNC OEM buyers also join the development team. The reason for creating this department was to promote simultaneous development system. The speed of product development increased because of such simultaneous development, since time is becoming one of the means of competition. Moreover, it facilities the just-in-time system with little buffer stock, which basically relies upon the communication between departments. Finally, it stimulates creativity. Communication between members with different knowledge and attitudes stimulates new thoughts, since DPS is a cross functional team.

\section{SYSTEMS AND RULES}

Rules can change behavior patterns when they are accepted by members and when they are supported by intrinsic rewards. With this fact, system and rules which were changed / have been are identified through interviews and they were

i) Communication System

ii) Suggestion System

iii) Rules that encouraged customer oriented behavior

iv) Human Resource Management System

\section{i) Communication System:-}

Through interview it was found that morning meetings were followed to bring in required transformation. Reason for conducting morning meeting was to provide information to plan for the day, based on the present situation or present requirement of customer, or issues within the company and the plant. It stimulates and solicits new ideas. Without information on the issues, new ideas will not be generated".

\section{ii) Suggestion Systems:-}

The IACM firms followed suggestion system as one of the important systems to bring change in employee's attitude. In the suggestion system ideas are presented by each workers every month and based on the quality of suggestion monetary rewards range from Rs.2000 to Rs.30000 and name of those who presented many good ideas are displayed on the wall". So it can be inferred that suggestion systems encourages members to change the traditional way of performing jobs and to present new ideas.

\section{iii) Rules that encouraged customer oriented behavior}

The customer oriented behavior was fostered through "rules concerning quality circle activities, and rules to enforce 5Ss, rules directing members to be quality conscious, always seeking to improve quality of products. These rules do not necessarily gain internal acceptance nor do they always lead to new habits. Ideally, in the prescriptive mode, the desired behavior should result in increased satisfaction among customers".

\section{iv) Human Resource Management System}

The IAMs were found to use human resource management system to change the attitude among employees for transformation / vitalizing the corporate culture through following four principles.

a) Sharing Values: Sharing the same value regarding innovation and introducing a diversity of capabilities is one of the effective principles. This was done through recruitment system of company, as highlighted by HRM of firm "Recruitments can introduce those who have a "challenging spirit", whose values are innovation oriented, and thus the company can reinforce the values".

b) Matching individuals' expectation with the needs of organization

c) Expansion of information and knowledge: this is done through formal training, which also becomes source of new ideas.

d) Encouragement of new ideas and willingness to change: this value is enforced by promotion and salary structure, merit rating system and retirement systems.

\section{DISCUSSION}

Adoption process of IACMs indicated oligopolistic reaction theory, where firms become multinational in order to match the actions of other member of oligopoly, which adopt the same cultural background of their buyers. The research indicates that major adoption was made in management policy, where organizational policy and structure have been changed to accelerate the smooth flow of transformation in organization. Thus this research study is validated where internationalization process is based on adoption and learning i.e., learning by doing model rather than knowledge-based models, which were used in previous studies to explain about strengthen business relationship between buyer-supplier and as well as for explaining the internationalization behavior of firms.

\section{REFERENCES}

1. Atanasopoulou, P. (2009). Relationship quality: a critical literature review and research agenda. European Journal of Marketing., 43(5): 583-610.

2. Barney, J.B. (1986). Firm resources and sustained competitive advantage. Journal of Management.,17(1): 99-120.

3. Brennan, R., Turnball, P.W. and Wilson, D.T. (2003). Dyadic adaptions in business-to-business markets. European Journal of Marketing., 37(12): 1636-1665.

4. Caniels, M.C.J. and Gelderman, C.J. (2007). Power and interdependence in buyer supplier relationships: A purchasing portfolio approach. Industrial Marketing Management., 36: 219-229.

5. Cavanagh, S. (1997). Content analysis: concepts, methods and applications. Nurse Researcher., 4(3): 5-16.

6. Dyer, J. et al.,(2001). Value creation and success in strategic alliances: alliancing skills and the role of alliance structure and systems. European Management Journal, 19 (5): 463-471.

7. Hallen, L., Johanson, J. and Sayed-Mohamed, N. (1991). Inter-firm adaptation in business relationships. Journal of marketing, 55 (2): 29-37.

8. Jap, S.D., Manolis, B.A. and Weitz, B.A. (1999). Relationship quality and buyer-seller interactions in 
channels of distribution. Journal of business research, 46 : 303-313.

9. Lai, C.S. (2007). The effects of influence strategies on dealer satisfaction and performance in Taiwan's motor industry. Industrial Marketing Management, 36: 518-527.

10. Lindgreen, A. and Wynstra, F. (2005). Value in business markets: What do we know? Where are we going?.Industrial Marketing Management., 34 (7): 732 748.

11. Mohanty, M.K. (2012). Buyer supplier relationship in manufacturing industry - findings from Indian manufacturing sector. Business Intelligence Journal, 21 (3): 319 - 333.

12. Palmatier, R.W., Dant, R.P., Grewal, D. and Evans, K.R. (2006). Factors influencing the effectiveness of relationship marketing: A meta-analysis. Journal of marketing, 70 (2) 136- 153.

13. Robbins, S.P. and Timothy, A.J. (2003). Essentials of Organizational Behavior. Global Serial: Pearson Education.

14. Uzzi, B.(1997). Social Structure and Competition in Interfirm Networks: The Paradox of Embeddedness. Administrative Science Quarterly., 42 (1): 35-67.

15. Wilson, D.T. and Jantrania, S. (1995). Understanding the value of a relationship. Asia-Australia Marketing Journal., Vol. 32, No. 2, pp. 55-66. 